\title{
Urinmikroskopi - et viktig diagnostisk verktøy
}

\author{
Mikroskopi av urinsedimenter er en enkel og billig, men ofte lite påaktet prosedyre. Med litt øvelse kan det \\ bidra til rask og korrekt diagnose der det er spørsmål om sykdom i nyrer og urinveier.
}

Heidi Andersen

heidi.andersen80@gmail.com

Ludvig N.W. Daae

Tale Norbye Wien

Etter hvert som det er kommet et stort utvalg av blodprøver og gode strimler (stiks) for testing av urin, ser det for oss ut som at urinmikroskopi ofte blir glemt både $i$ hverdagen og i litteraturen ved utredning av sykdommer i nyrer og urinveier. Det finnes imidlertid europeiske retningslinjer der viktigheten av urinunders $ø$ kelse, inkludert mikroskopi, fremheves (1). I det følgende vil vi kort oppsummere disse retningslinjene, for så å vise med pasienteksempler hva man kan gå glipp av ved ikke å mikroskopere urinprøven.

\section{Europeiske retningslinjer}

Ifølge retningslinjene fra European Confederation of Laboratory Medicine (ECLM) (1) er det tre viktige indikasjoner for strimmeltesting og eventuell mikroskopi av urin:

- Mistanke om eller oppfølging av symptomer og situasjoner som taler for urinveisinfeksjon

- Mistanke om eller oppfølging av ikkeinfeksiøs nyresykdom, enten primært eller sekundært til systemsykdommer som revmatiske lidelser, hypertensjon, svangerskapsforgiftning eller legemiddelbivirkninger

- Mistanke om eller oppfølging av postrenal sykdom

Retningslinjene opererer med to kunnskapsnivåer når det gjelder urinmikroskopi. Basisnivået er minimum for alle som skal undersøke urinprøver og omfatter beskrivelse og gjenkjenning av erytrocytter, leukocytter, epitelceller, hyaline/ikke-hyaline sylindre, bakterier, Trichomonas, spermier, artefakter (hår/fibre etc.), fettdråper og krystaller. På avansert nivå går man $\mathrm{i}$ detalj inn på elementene over, f.eks. isomorfe/dysmorfe erytrocytter, subklassifisering av epitelceller, sylindre, bakterier osv.

Allerede her vil vi påpeke at det ved positive utslag på strimmeltest er viktig å skille mellom reell sykdomsårsak og forurensning av prøven (fig 1), noe som kun kan avgjøres ved mikroskopi.

\section{Illustrerende kasuistikker}

Pasient 1. Pasienten ble innlagt i sykehus med økende tungpustethet, ødemer i beina, generell uvelhetsfølelse i kroppen og makroskopisk hematuri. Fra tidligere hadde pasienten kjent atrieflimmer, hypertensjon, iskemisk hjertesykdom og diabetes type 2. Klinisk status ved innkomsten var upåfallende - bortsett fra atrieflimmer, pittingødemer i underekstremitetene og overvekt.

Blodprøve viste forhøyet kreatininnivå, $114 \mathrm{\mu mol} / \mathrm{l}$, med estimert glomerulær filtrasjonrate (eGFR) på $42 \mathrm{ml} / \mathrm{min} / 1,73 \mathrm{~m}^{2}$. Urinstiks viste rikelig med leukocytter (> 500 leukocytter/ $\mu$ l urin), moderat mengde erytrocytter $(\approx 80$ erytrocytter/ $\mu l)$ og lett albuminuri $(0,3 \mathrm{~g} / \mathrm{l})$. Urinmikroskopiavslørte moderat mengde isomorfe (intakte) erytrocytter (7-25 erytrocytter per synsfelt forstørret $40 \times$ ) (fig 2), moderat mengde hyaline sylindre (funn av hyaline sylindre $i$ annethvert synsfelt ved en forstørrelse på $40 \times 1$ samt noen plateepitelceller (1-5 plateepitelceller per synsfelt ved en forstørrelse på $40 \times$ ).

Videre utredning med røntgen thorax og ekkokardiografi påviste hjertesvikt, og det ble startet behandling. CT abdomen viste lokalisert veggfortykkelse i urinblæren, og pasienten ble henvist til urolog med spørsmål om blæretumor som årsak til hematuri.

Urinstiks gir utslag både på intakte og ødelagte erytrocytter samt på fritt hemoglobin og myoglobin, mens mikroskopi vil kunne bidra til å avgjøre hvor erytrocytter i urinen stammer fra. Isomorfe erytrocytter i urinen betyr at de røde blodcellene har sin naturlige form og størrelse, i motsetning til dysmorfe erytrocytter, som er deformert etter passasje gjennom glomerulær kapillærvegg ved sykdom i glomeruli. De kan vises i urinen som akantocytter, blyantceller, elliptocytter eller fragmenter.

Isomorfe erytrocytter har regulær, bikonkav form, er resultat av postglomerulær blødning og stammer fra nyretubuli, nyrebekken, ureter, blære eller urethra. Alminnelige årsaker til isomorf hematuri er uttalt venøs stuvning i urinveiene, urinveisinfeksjon og kreft. Hos den omtalte pasienten lå alle disse mulighetene åpne, og et rasjonelt undersøkelsesopplegg ble initiert som følge av urinmikroskopien.
Pasient 2. Pasienten ble lagt inn i sykehus etter et døgns sykehistorie med magesmerter med takvis forverring, slapphet og kvalme. Klinisk undersøkelse var upåfallende, bortsett fra hypertensjon (blodtrykk 195/140 $\mathrm{mm} \mathrm{Hg}$ ). I blodprøven var kreatininverdien patologisk forhøyet til $183 \mu \mathrm{mol} / \mathrm{l}$, de øvrige blodprøveresultater var normale.

Urin ved innkomst viste følgende stiksutslag: leukocytter moderat $\approx 70-125$ leukocytter/ $\mu$ l), nitritt negativ, glukose moderat $(14-28 \mathrm{mmol} / \mathrm{l})$, albumin moderat $(0,3-1 \mathrm{~g} / \mathrm{l})$, erytrocytter rikelig ( $\approx 200$ per $\mu$ l).

Mikroskopi viste svært mange tubulusepitelceller (store flak) (fig 3), moderat antall cellecylindre av tubulusepitel (4-10 $i$ hele preparatet), moderat antall erytrocytter og leukocytter (7-25 per synsfelt med forstørrelse $40 \times$ ) (fig 4). Funnene var forenlig med akutt tubulær nekrose.

Røntgen abdomen og thorax samt CT urinveier uten kontrast ga ingen forklaring på pasientens symptomer. Magesmertene ble oppfattet som mulig obstipasjon, og pasienten fikk intravenøs væske og antihypertensiver. Neste dag var kreatininverdien i serum steget til 551 umol/l og urinproduksjonen var fallende, på tross av intravenøs væskeinfusjon. Pasienten ble derfor overført til nyreavdeling. Nyrebiopsi viste iskemisk nyreskade (akutt tubulær nekrose). Tre måneder senere var pasienten fortsatt avhengig av dialyse.

Dersom man hadde tatt utgangspunkt i urinfunnene hos denne pasienten ved innkomst, ville nyreskaden vært erkjent før kreatininverdi og andre blodvariabler ble alarmerende forhøyet. Akutt tubulær nekrose er akutt nyresvikt hvor tubulusepitelceller tapes på grunn av iskemi og/eller toksisk skade.

Mikroskopi av urinen er nyttig for å skille akutt tubulær nekrose fra prerenal nyresvikt, hvor det ikke er strukturell nyreskade. Ved akutt tubulær nekrose finnes typisk tubulusepitelsceller og cellesylindre av tubulusepitel i urinen, som hos vår pasient.

Pasient 3. Pasienten ble innlagt i sykehus etter noen ukers sykehistorie med slapphet og frysninger, de siste dagene med mørk urin og hudkløe. Blodprøvene viste sterkt forhøyet kreatininnivå på $2449 \mu \mathrm{mol} / \mathrm{l}$, urinstoff 46,2 mmol/log kalium 6,4 $\mathrm{mmol} / \mathrm{l}$. Urinstiks viste betydelig proteinuri og hema- 


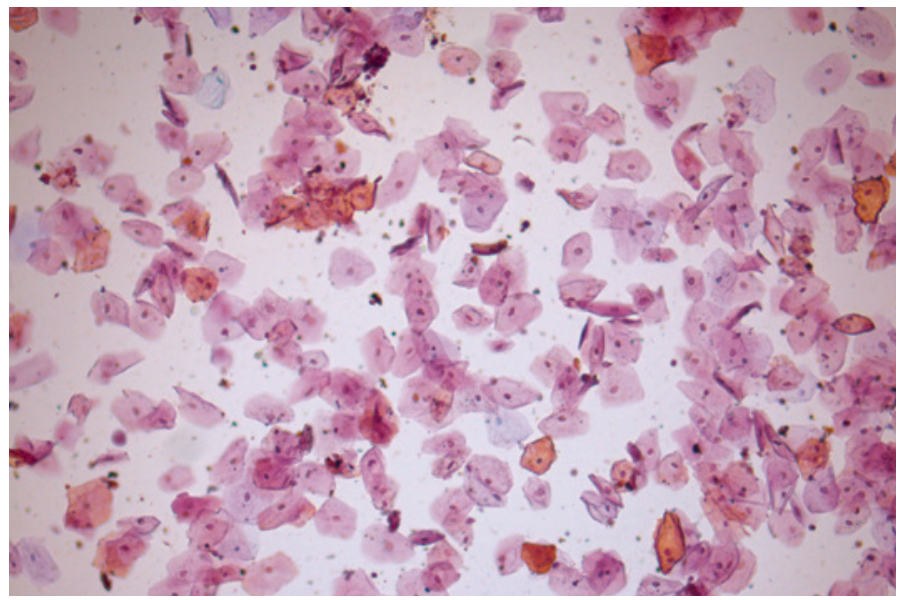

Figur 1 Urinsediment forstørret ti ganger viser tallrike epitelceller. Slike celler stammer fra genitalia og er tegn på at anbefalte prosedyrer for urinprøvetaking ikke er fulgt. Ofte følger også bakterier og vanskelig identifiserbare elementer med. Ved > 5 plateepitelceller i urinsedimentet mikroskopert med forstørrelse 40 ganger angir vi at prøven er forurenset og ber om ny og korrekt tatt prøve for å få et pålitelig prøveresultat

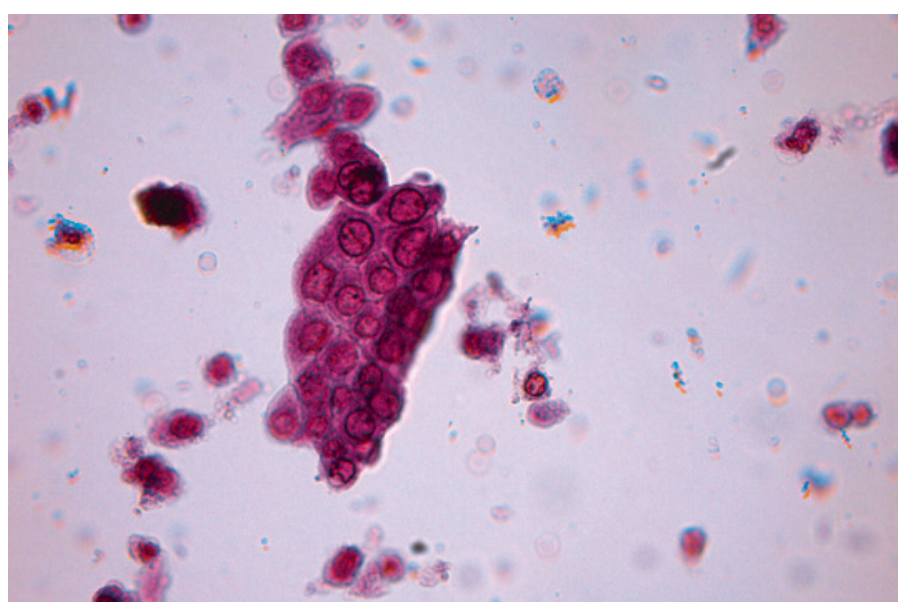

Figur 3 Urinsediment forstørret 40 ganger viser rikelig med tubulusepitelceller. Et slikt funn har stor diagnostisk betydning og indikerer skade av nyretubuli (her akutt tubulær nekrosel

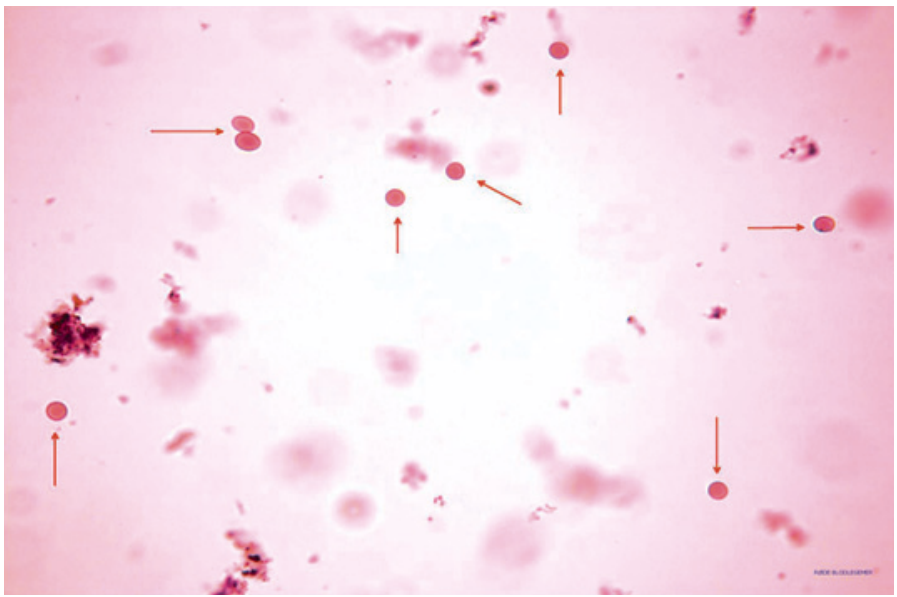

Figur 2 Urinsediment forstørret 40 ganger viser mange intakte (isomorfe) erytrocytter. Dette er tegn på postglomerulær blødning (fra nyretubuli, nyrebekken, ureter, blære eller urethra). Overvekt av dysmorfe (irregulære, fragmenterte) erytrocytter peker derimot på glomerulær hematuri (ikke vist)

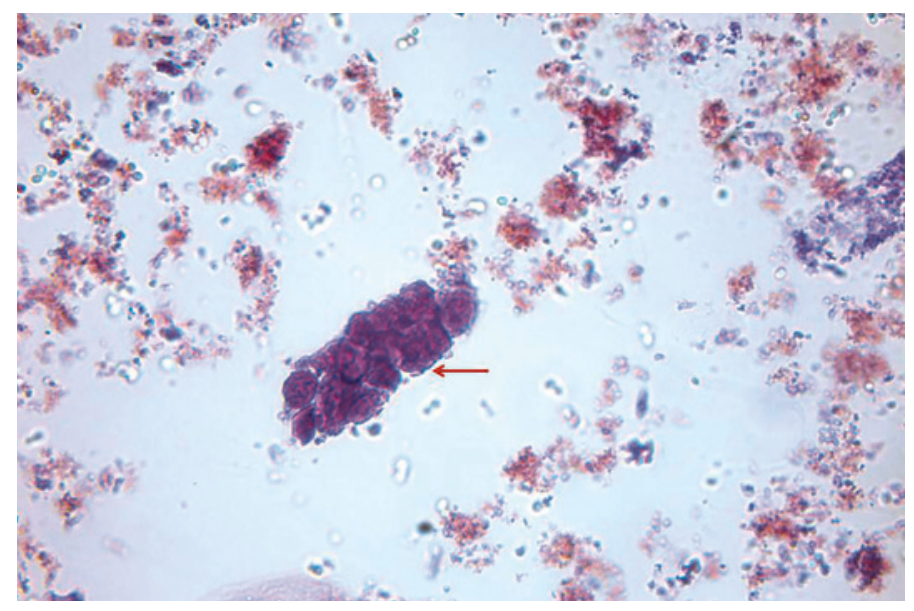

Figur 4 Urinsediment forstørret 40 ganger viser en cellesylinder. Disse dannes ved at celler (i dette tilfellet tubulusepitelceller) innleieres i proteinavstøpninger av tubuli. Funnet er alltid et alvorlig sykdomstegn og skyldes ofte, som i dette tilfellet, akutt tubulær nekrose turi (henholdsvis > $20 \mathrm{~g} / \mathrm{log} \approx 200$ erytrocytter per $\mu$ ll.

Mikroskopi viste et nefrittisk bilde, preget av glomerulær hematuri med moderat mengde dysmorfe erytrocytter (7-25 erytrocytter per synsfelt med forstørrelse $40 \times$ ), rikelig mengde vokssylindere $1>4 \mathrm{i}$ hele preparatet). Videre fantes det rikelig med tubulusepitelceller, moderat tilstedeværelse av kornete sylindre (4-10 i hele preparatet) og noen cellesylindre (1-3i hele preparatet) (fig 5). Pasienten ble samme dag overført til nyreavdeling med mistanke om akutt glomerulonefritt, som ble påvist ved nyrebiopsi. Adekvat behandling ble igangsatt.

Vokssylindre er alltid et alvorlig tegn og er kun til stede ved patologiske tilstander.
I tilfeller med så høyt kreatininnivå i serum som hos denne pasienten ville nok rask overflytting til nyreavdeling skjedd uansett, men urinmikroskopien ga her viktig tilleggsinformasjon om hastegrad for videre diagnostikk og behandling.

\section{Forbedringspotensial}

Til tross for at urinmikroskopi altså kan gi helt nødvendig og avgjørende informasjon $i$ utredning av en pasients sykdom, er det vårt inntrykk at mikroskopi ofte utelates både i litteraturen og $\mathrm{i}$ hverdagen. For eksempel ble det nylig publisert en nordisk artikkel om nyrefunksjonsvariabler ved akutt nyresvikt der urinmikroskopi ikke er nevnt (2). Enkelte sykehuslaboratorier tilbyr ikke mikroskopi av urinen lenger.
Vi erfarer at interessen for urinmikroskopi er varierende. En fordypningsoppgave i urinmorfologi utført ved Diakonhjemmet Sykehus i 2008 viste at det var et stort forbedringspotensial hos leger og bioingeniører når det gjaldt å oppfylle de europeiske retningslinjenes minimumskrav til basiskunnskap innen urinmorfologi $(1,3)$.

Dette kan ha flere årsaker. Det kreves relativt lang og god opplæring i analysen, og kompetansen må holdes ved like. To norske verk til støtte og opplæring på dette feltet ble utgitt i $2012(4,5)$. Siden bestemmelse av kreatinin, eGFR og cystatin $\mathrm{C}$ for tiden er mye omtalt ved spørsmål om sykdommer i nyrer og urinveier, er det lett å glemme at urinmikroskopien kan gi raskere og, i mange tilfeller, mer adekvat informasjon. 


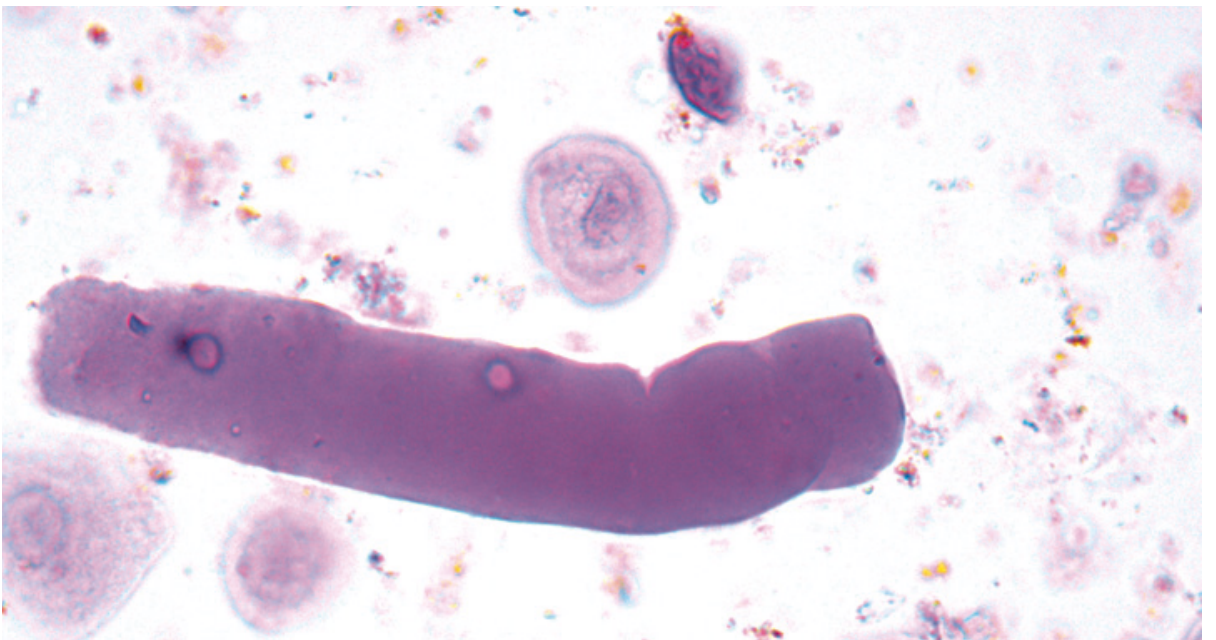

Figur 5 Urinsediment forstørret 40 ganger viser en såkalt vokssylinder. Slike sylindre er oftest avstøpninger av de brede partiene av tubuli, de ser «voksaktige» ut, men består hovedsakelig av lgG. De assosieres med alvorlig, ofte terminal nyresykdom

\section{Forurensede prøver}

Som nevnt innledningsvis er det kun ved urinmikroskopi at man kan avgjøre om en urinprøve er forurenset eller ikke. Urinprøver kan forurenses under prøvetaking ved at vaginal utflod og hudflora blandes i urinen dersom prosedyrer med vaskeprøve og midtstråleurin ikke følges $(1,4,5)$. Vi setter tilstedeværelse av fem eller flere epitelceller ved mikroskopi med forstørrelse 40 ganger som tegn på forurensning. Vi sender da ikke prøven til mikrobiologisk dyrking, men angir at den er forurenset og anbefaler ny og korrekt prøvetaking.

Forurensede urinprøver er et utbredt problem $(1,4,5)$. Vi har telt over prøvene mikroskopert på vårt laboratorium og fant at omtrent $25 \%$ av de vel 300 urinprøvene som blir mikroskopert per måned er forurenset. Dyrking av forurensede prøver gir svar uten klinisk relevans og kan føre til at pasienter får unødvendig antimikrobiell behandling dersom en antatt urinveisinfeksjon behandles ut fra positiv strimmeltest uten mikroskopisk kontroll. Dessuten vil dyrkning av forurensede prøver påføre helsevesenet unødvendige kostnader. Dersom de forurensede prøvene ved vårt sykehus var blitt videresendt for dyrking for den nåværende taksten på 104 kroner per urin, ville det ha betydd ca. 100000 kroner $\mathrm{i}$ årlig kostnad for sykehuset.

\section{Nyttig verktøy}

Som pasienteksemplene over illustrerer kan urinmikroskopi hjelpe klinikeren å skille mellom glomerulær og postglomerulær hematuri (pasient 1), påvise akutt nyreskade tidligere enn ved hjelp av kreatininstigning (pasient 2) og påvise et nefrittisk bilde hvor igangsetting av adekvat behandling haster (pasient 3).
Akutt nyresvikt er en relativt vanlig diagnose og er forbundet med økt dødelighet hos pasienter i sykehus (6). Prerenal sykdom og akutt tubulær nekrose er de vanligste årsakene til akutt nyresvikt $(6,7)$. Diagnosen skal stilles på bakgrunn av sykehistorie, somatisk undersøkelse, blod- og urinprøver, inkludert urinmikroskopi (8). I flere artikler er det vist god korrelasjon mellom ulike funn i urinsedimenter og sykdom, som for eksempel tilstedeværelse av kornete sylindre og cellesylindre av tubulusepitel ved akutt tubulær nekrose $(9,10)$. Likevel er bruken av urinmikroskopi fortsatt varierende $(2,11)$, og urinmikroskopiens rolle og betydning i moderne klinisk praksis mangelfullt vektlagt og beskrevet (12).

Det er velkjent at nivået av kreatinin i serum alene ikke nødvendigvis avspeiler graden av nyreskade hos en pasient, slik vi så hos pasient 2. Spesielt er dette aktuelt ved akutt nyresvikt. Urinmikroskopi er da et nyttig diagnostisk verktøy som oppfyller alle krav man kan stille til en ideell prognostisk test - enkel og billig å utføre, lett tilgjengelig, med evnen til å skille ulike tilstander og til å predikere en diagnose før manifest sykdom oppstår. Det er blitt utviklet flere skåringssystemer for urinsediment som er vist å kunne predikere forverring av akutt nyresvikt (10-13).

Nye biomarkører utprøves, og flere steder er f.eks. cystatin $\mathrm{C}$ innført i utredningen av nyresykdommer. Det er imidlertid kjent at nivået av så vel kreatinin som cystatin $\mathrm{C}$ ofte øker forholdsvis sent ved akutte nyresykdommer, som hos pasient 2. Det er derfor med god grunn at de europeiske retningslinjene for urinanalyse fortsatt anbefaler urinmenter til biokjemiske prøver ved mistanke om eller symptomer på nyresykdom (1). stiks og urinmikroskopi som viktige supple-

\section{Heidi Andersen (f. 1980)}

er bioingeniør og har en mastergrad i molekylær biovitenskap og spesialistgodkjenning innen medisinsk morfologi. Hun arbeider ved Avdeling for medisinsk biokjemi, Diakonhjemmet Sykehus.

Forfatter har fylt ut ICMJE-skjemaet og oppgir følgende interessekonflikter: Hun har copyright på 188 bilder i en urinmikroapplikasjon (4)

\section{Ludvig N.W. Daae (f. 1934)}

er dr.med. og overlege ved Avdeling for medisinsk biokjemi, Diakonhjemmet Sykehus. Han har tidligere skrevet flere artikler om urinundersøkelse.

Forfatter har fylt ut ICMJE-skjemaet og oppgir ingen interessekonflikter.

\section{Tale Norbye Wien (f. 1968)}

er spesialist i indremedisin og lege i spesialisering i nyresykdommer ved Nyremedisinsk avdeling, Oslo universitetssykehus.

Forfatter har fylt ut ICMJE-skjemaet og oppgir ingen interessekonflikter.

\section{Litteratur}

1. European Confederation of Laboratory Medicine. European urinalysis guidelines. Scand J Clin Lab Invest Suppl 2000; 231: 1-86.

2. Mårtensson J, Bell M. Njurfunktionsmätningar inom intesivvården. Klinisk Biokemi i Norden 2014; $26: 36-9$.

3. Andersen H. Urinmorfologi på lokalsykehusnivå. Bioingeniøren 2009; 44: 12-4

4. Andersen H, Wien TN, Daae LNW. Urinemicro. App for Iphone og androidtelefoner. Søkeord urinemicro. Oslo: Diakonhjemmet Sykehus, 2012

5. Vinje BU. Urinmikroskopi - praktisk utførelse og bildeatlas. Kristiansand: Capppelen Damm Høyskoleforlaget, 2012

6. Mehta RL, Pascual MT, Soroko S et al. Spectrum of acute renal failure in the intensive care unit: the PICARD experience. Kidney Int 2004; 66: 1613-21.

7. Rabb H. Evaluation of urinary markers in acute renal failure. Curr Opin Nephrol Hypertens 1998; 7: $681-5$.

8. Marcussen N, Schumann J, Campbell P et al. Cytodiagnostic urinalysis is very useful in the differential diagnosis of acute renal failure and can predict the severity. Ren Fail 1995; 17: 721 -9.

9. Schentag JJ, Gengo FM, Plaut ME et al. Urinary casts as an indicator of renal tubular damage in patients receiving aminoglycosides. Antimicrob Agents Chemother 1979; 16: 468-74

10. Chawla LS, Dommu A, Berger A et al. Urinary sediment cast scoring index for acute kidney injury: a pilot study. Nephron Clin Pract 2008. 110: c145-50

11. Perazella MA, Coca SG, Hall IE et al. Urine microscopy is associated with severity and worsening of acute kidney injury in hospitalized patients. Clin J Am Soc Nephrol 2010. 5: 402-8.

12. Perazella MA, Coca SG. Traditional urinary biomarkers in the assessment of hospital-acquired AKI. Clin J Am Soc Nephrol 2012; 7: 167-74.

13. Macedo E, Mehta RL. Biomarkers for acute kidney injury: combining the new silver with the old gold. Nephrol Dial Transplant 2013; 28: 1064-7.

Mottatt 7.2. 2014, første revisjon innsendt 26.5. 2014, godkjent 3.7. 2014. Redaktør: Hanne Støre valeur. 